\title{
Reversible hydration of the perchlorate-intercalated layered double hydroxides of Li and Al: structure models for the dehydrated phases
}

\author{
LATHA PACHAYAPPAN and P VISHNU KAMATH* (1) \\ Department of Chemistry, Central College, Bangalore University, Bangalore 560 001, India \\ *Author for correspondence (vishnukamath8@ hotmail.com)
}

MS received 14 January 2020; accepted 23 April 2020

\begin{abstract}
Imbibition of lithium sulphate into aluminium hydroxide is known to result in a sulphate-intercalated layered double hydroxide ( $\mathrm{LDH}$ ) of $\mathrm{Li}$ and $\mathrm{Al}$. The perchlorate ion has the same size and molecular symmetry as the sulphate ion, but only half its charge. Consequently, twice the number of $\mathrm{ClO}_{4}^{-}$ions is needed to balance LDHs the charge on the metal hydroxide layer, compared to the $\mathrm{SO}_{4}^{2-}$ ions. In this work, the $\mathrm{ClO}_{4}^{-}$-intercalated $\mathrm{LDHs}$ were obtained from both the bayerite and gibbsite precursors. Inclusion of the hydration sphere along with the $\mathrm{ClO}_{4}^{-}$anion, induced turbostratic disorder in the stacking of the metal hydroxide layers. Temperature-induced dehydration $\left(T \sim 100-140^{\circ} \mathrm{C}\right)$ brought about a partial ordering in the interlayer region and the $\mathrm{ClO}_{4}^{-}$ion oriented itself with one of its $C_{2}$-axes parallel to the metal hydroxide layer. The close packing of $\mathrm{ClO}_{4}^{-}$ions could be realized by the complete dehydration of $\mathrm{LDH}$ and the distribution of the $\mathrm{ClO}_{4}^{-}$ions in all the available interlayer sites. In contrast, within the crystal of the sulphate analogue, the sulphate ions occupy only half the number of interlayer sites. The other half is occupied by the residual water molecules, as the sulphate analogue does not fully dehydrate even at elevated temperatures. This difference in the behaviour of the two LDHs has its origin in the large difference in the hydration enthalpies of the two anions.
\end{abstract}

Keywords. Layered double hydroxide; aluminium hydroxide; perchlorate; sulphate.

\section{Introduction}

$\mathrm{Al}(\mathrm{OH})_{3}$ has a layered structure, in which a third of the cationic sites are vacant [1-4]. The layer composition is $\left[\mathrm{Al}_{2} \square(\mathrm{OH})_{6}\right]$ ( $\square$ : cation vacancy). A positive charge can be generated in the metal hydroxide layer by inserting $\mathrm{Li}^{+}$ions in the cation vacancies. The two-cation (double)-hydroxide layer acquires the composition $\left[\mathrm{Al}_{2} \mathrm{Li}(\mathrm{OH})_{6}\right]^{+}$. To compensate the positive charge, an interlayer of anions and water molecules of the composition $\left[\left(\mathrm{A}^{n-}\right)_{1 / n} \cdot y \mathrm{H}_{2} \mathrm{O}\right]$ is incorporated simultaneously with the imbibition of $\mathrm{Li}^{+}$in the metal hydroxide layer $[5,6]$. The resulting phase has the composition $\left[\mathrm{LiAl}_{2}(\mathrm{OH})_{6}\right]\left(\mathrm{A}^{n-}\right)_{1 / n} \cdot y \mathrm{H}_{2} \mathrm{O}$.

A range of anions such as $\mathrm{NO}_{3}^{-}, \mathrm{Cl}^{-}, \mathrm{Br}^{-}, \mathrm{CO}_{3}^{2-}$ and $\mathrm{SO}_{4}^{2-}$ have been successfully intercalated into the interlayer gallery of [Li-Al] layered double hydroxides (LDHs), and their structures are reported [7-13]. The size, charge, degree of hydration and molecular symmetry of the anion not only determine the basal spacing in the LDHs, but also the manner in which the metal hydroxide layers are stacked. Consequently, different anions select for different polytypes.
The $\mathrm{CO}_{3}^{2-}$ ions are planar and crystallize LDHs with prismatic interlayer sites, wherein there is a coincidence of the molecular symmetry of the anion with the local symmetry of the interlayer site. The $\mathrm{CO}_{3}^{2-}$ ion is intercalated with its molecular plane parallel to the metal hydroxide layer (local symmetry $D_{3 h}$ ) with a basal spacing of $7.5 \AA$. The H-bonding between the $\mathrm{OH}$ groups of the layer and the ' $\mathrm{O}$ ' atoms of the $\mathrm{CO}_{3}^{2-}$ ion is maximized in this mode of coordination, and there is a perfect registry between the carbonate ion sublattice and the metal hydroxide layer [14]. In the nitrate-intercalated LDHs, twice the number of nitrate ions as the number of carbonate ions is included within the same interlayer space. The tight packing of nitrate ions in the interlayer results in strong anisotropic repulsive forces, and generates incommensurate structures, wherein the unit mesh of nitrate ions in the interlayer is not in registry with the metal hydroxide layer. Simultaneously, the nitrate ions reorient themselves in such a way that their molecular plane is tilted at an angle to the metal hydroxide layer and the basal spacing increases to $8.8 \AA[10,12]$.

Sulphate and perchlorate ions constitute another pair of isostructural ions with a similar size but different charge. 
The sulphate ion has been shown to intercalate in the interlayer region in an approximately $D_{2 d}$ local symmetry with one of the $C_{2}$-axes of $\mathrm{SO}_{4}^{2-}$ being normal to the metal hydroxide layer [13], in the gibbsite-derived LDH. In the bayeritederived LDH, the orientation of the sulphate ion is different, and the local symmetry is further reduced. These orientations are selected to maximize the $\mathrm{H}$-bonding between the $\mathrm{O}$ atoms of the sulphate ions and the metal hydroxide layers. The perchlorate-intercalated [Li-Al] LDH was shown to undergo a reversible expansion of the basal spacing on humidity cycling [15], but no attempt was made in this early study to investigate the structure of the LDH or the orientation of the intercalated ions.

The main objective of this work was to obtain structure models to predict the manner in which twice the number of perchlorate ions is packed within the same interlayer space as occupied by the sulphate ions. A second objective was to examine if the perchlorate-LDH undergoes interpolytype transitions on variation of humidity and temperature.

\section{Experimental}

\subsection{Synthesis}

Gibbsite used in this study was a gift from Jawaharlal Nehru Aluminum Research Development and Design Centre (JNARDDC), Nagpur, India. Bayerite was synthesized in the laboratory by a procedure reported in the literature [16]. The [Li-Al- $\mathrm{ClO}_{4}$ ] LDHs were synthesized by soaking $\sim 2 \mathrm{~g}$ of gibbsite or bayerite in $\sim 18 \mathrm{M} \mathrm{LiClO}_{4} \cdot 3 \mathrm{H}_{2} \mathrm{O}$ solution taken in a screw cap vial. The vial was immersed in an oil bath at $90^{\circ} \mathrm{C}$ for 7 days with constant stirring. The sample was then aged at $90^{\circ} \mathrm{C}$ for $30 \mathrm{~h}$ without stirring [17]. The precipitate obtained was centrifuged and washed with water. The solid sample was dried in a hot air oven maintained at $60^{\circ} \mathrm{C}$. The LDHs prepared are denoted as g- $\left[\mathrm{Li}-\mathrm{Al}-\mathrm{ClO}_{4}\right]$ and b- $\left[\mathrm{Li}-\mathrm{Al}-\mathrm{ClO}_{4}\right]$ (g: gibbsite derived; b: bayerite derived), respectively.

\subsection{Characterization}

The LDHs were analysed for their $\mathrm{Li}^{+}$content by flame photometry, $\mathrm{ClO}_{4}^{-}$content by ion chromatography (Metrohm Model 861 Compact Ion Chromatograph fitted with a Metrosep SUP150 column) and $\mathrm{Al}^{3+}$ content by gravimetry. The estimations yielded a $\mathrm{Li} / \mathrm{Al}$ ratio of 0.39 for $\mathrm{g}$-[ $\left.\mathrm{Li}-\mathrm{Al}-\mathrm{ClO}_{4}\right]$ and 0.37 for $b-\left[\mathrm{Li}-\mathrm{Al}-\mathrm{ClO}_{4}\right] \mathrm{LDHs}$, respectively. The ratio is less than the ideal value $(0.5)$ expected. The $\mathrm{ClO}_{4}^{-}$content was nevertheless equivalent to the $\mathrm{Li}^{+}$content within the limits of experimental error. The nominal composition $\left(\left[\mathrm{Li}^{+}\right] /\left[\mathrm{ClO}_{4}^{-}\right]=1\right)$ was assumed for the $\mathrm{LDH}$ phases. The $\mathrm{Al}$ in excess of the ideal $\mathrm{Li} / \mathrm{Al}$ ratio was attributed to the unreacted precursor, gibbsite or bayerite. The composition of the product in the two cases was $\mathrm{Li}_{0.44} \mathrm{Al}(\mathrm{OH})_{3}\left(\mathrm{ClO}_{4}\right)_{0.44}+$ $0.12\left[\mathrm{Al}(\mathrm{OH})_{3}\right]$ and $\mathrm{Li}_{0.5} \mathrm{Al}(\mathrm{OH})_{3}\left(\mathrm{ClO}_{4}\right)_{0.5}+0.34\left[\mathrm{Al}(\mathrm{OH})_{3}\right]$ for g- $\left[\mathrm{Li}-\mathrm{Al}-\mathrm{ClO}_{4}\right]$ and b-[Li-Al- $\left.\mathrm{ClO}_{4}\right] \mathrm{LDHs}$, respectively.
The powder X-ray diffraction (PXRD) patterns of the samples were recorded using a Bruker D8 Advance diffractometer ( $\mathrm{Cu} \mathrm{K} \alpha$ radiation, $\lambda=1.5418 \AA$ ) operating in reflection geometry. In situ measurements were carried out at different temperatures, and relative humidity $(\mathrm{RH})$ values using an Anton Paar CHC plus Humidity Chamber as an attachment. The PXRD patterns were recorded over $5-100^{\circ} 2 \theta$ range. A step size of $0.02^{\circ} 2 \theta$ (counting time of $10 \mathrm{~s}$ per step) was used for data collection.

\subsection{PXRD pattern simulations and structure refinement}

The relationship between the successive layers in the LDH was established using the structural synthon approach described elsewhere in detail [14]. A Fortran-based computer code DIFFaX [18,19] was used to simulate the PXRD patterns of all the possible polytypes using different stacking vectors. A metal hydroxide layer obtained from the reported structure of $\mathrm{g}$-[Li-Al-X] $\left(\mathrm{X}=\mathrm{Cl}^{-}, \mathrm{Br}^{-}\right) \mathrm{LDH}$ [20] was identified as a structural synthon, and all its symmetry-related atoms were used as input. The Laue symmetry was declared UNKNOWN, and the DIFFaX code was allowed to compute the Laue symmetry. The DIFFaX code integrates the diffraction intensity layer by layer for an infinite stacking. A full-width at halfmaximum value of $0.2^{\circ} 2 \theta$ (Lorentzian profile function) was used to broaden the simulated Bragg reflections. A good match between the observed and the simulated PXRD patterns yielded a partial structure model based on the metal hydroxide layer and the stacking vector. The partial structure model was introduced in code FOX (Free Objects for Crystallography) [21] to obtain the positions of the $\mathrm{ClO}_{4}^{-}$ions in the interlayer.

\section{Results}

The PXRD pattern of the g-[Li-Al- $\left.\mathrm{ClO}_{4}\right]-\mathrm{ASP}$ (ASP: asprepared) phase exhibited strong basal reflections with spacings of $9.17 \AA\left(9.6^{\circ} 2 \theta\right)$ and $4.59 \AA\left(19.3^{\circ} 2 \theta\right)$, respectively (figure 1a). Upon heating to $140^{\circ} \mathrm{C}$, the $\mathrm{LDH}$ labelled as g-[Li-Al-ClO $\left.{ }_{4}\right]-\mathrm{T} 140$, showed a PXRD pattern with strong basal reflections at $8.74 \AA\left(10.1^{\circ} 2 \theta\right)$ and $4.37 \AA\left(20.3^{\circ} 2 \theta\right)$, respectively (figure $1 \mathrm{~b}$ ). Both the patterns also included a number of weak $h k l$ reflections in mid- $2 \theta$ region $\left(25-55^{\circ} 2 \theta\right)$, which could be indexed to two-layer hexagonal cells (table 1). On cooling and rehydration ( $\mathrm{RH} \sim 80 \%)$, a new phase was observed (g-[Li-Al-ClO 4 - RH80, figure 1c). The ingress of massive amounts of water resulted in the expansion of the basal spacing by $\sim 3$ to $11.82 \AA$ and strong $00 l(l=1,2,3,4$, $5)$ reflections are obtained. The complete absence of any $h k l$ reflections is indicative of a high degree of orientation.

The b-[Li-Al- $\left.\mathrm{ClO}_{4}\right]$-ASP phase comprised two structural motifs with different degrees of hydration corresponding to basal spacings of $11.63 \AA\left(7.6^{\circ} 2 \theta\right)$ and $9.21 \AA\left(9.6^{\circ} 2 \theta\right)$, respectively (figure $2 \mathrm{a}$ ). The difference in basal spacing of the two motifs $(\sim 2.5 \AA)$ matches the van der Waals diameter 


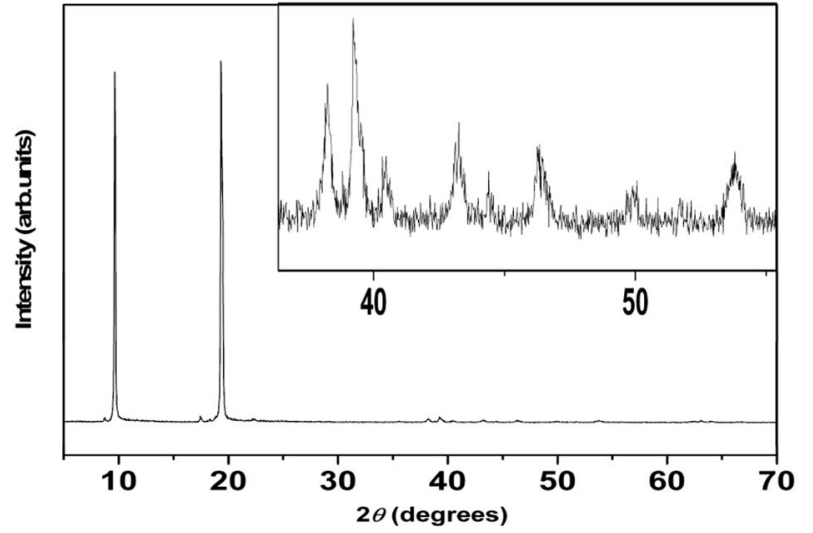

(a)

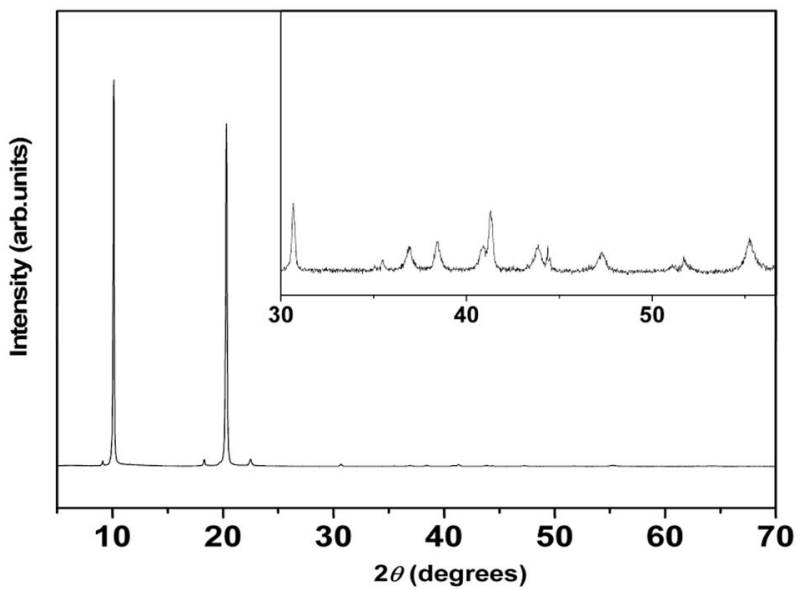

(b)

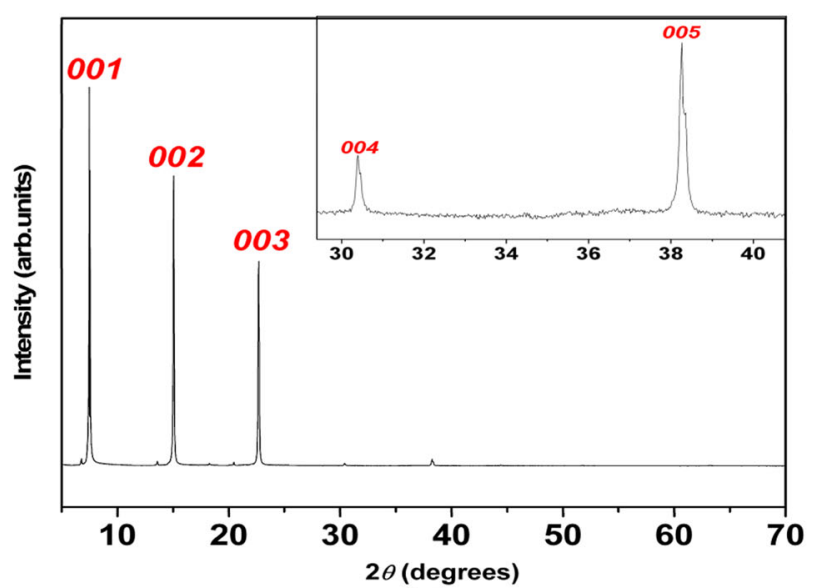

(c)

Figure 1. PXRD patterns of (a) g-[Li-Al-ClO 4$]-\mathrm{ASP}$, (b) g-[Li$\left.\mathrm{Al}-\mathrm{ClO}_{4}\right]-\mathrm{T} 140$ and (c) g-[Li-Al-ClO 4$]-\mathrm{RH} 80 \mathrm{LDH}$ phases. In the inset, the mid- $2 \theta$ region $\left(30-65^{\circ} 2 \theta\right.$ ) is expanded to show the weak reflections.

of a water molecule. The simultaneous presence of two structural motifs is indicative of the sensitivity of this phase to changes in the ambient temperature and humidity. On heating to $50^{\circ} \mathrm{C}$, the $9.14 \AA\left(9.7^{\circ} 2 \theta\right)$ phase (b-[Li-Al- $\left.\left.-\mathrm{ClO}_{4}\right]-\mathrm{T} 50\right)$ was
Table 1. Observed $2 \theta$ values and the corresponding indices of g-[Li-Al-ClO 4 -ASP and g-[Li-Al-ClO 4$]-T 140$ LDHs.

\begin{tabular}{|c|c|c|c|}
\hline \multicolumn{2}{|c|}{$\underline{\mathrm{g}-\left[\mathrm{Li}-\mathrm{Al}-\mathrm{ClO}_{4}\right]-\mathrm{ASP}}$} & \multicolumn{2}{|c|}{$\mathrm{g}-\left[\mathrm{Li}-\mathrm{Al}-\mathrm{ClO}_{4}\right]-\mathrm{T} 140$} \\
\hline \multicolumn{2}{|c|}{$\begin{array}{l}a=b=5.1021 \AA \\
c=18.3459 \AA, \beta=90^{\circ}, \\
\text { FM value }=14.14\end{array}$} & \multicolumn{2}{|c|}{$\begin{array}{c}a=b=5.1154 \AA, \\
c=17.4854 \AA, \beta=90^{\circ}, \\
\text { FM value }=26.5\end{array}$} \\
\hline $2 \theta^{\circ}$ & $h k l$ & $2 \theta^{\circ}$ & $h k l$ \\
\hline 9.6 & 002 & 10.1 & 002 \\
\hline 19.3 & 004 & 20.3 & 004 \\
\hline 38.2 & 113 & 22.5 & 102 \\
\hline 39.3 & 008 & 30.7 & 006 \\
\hline 40.4 & 114 & 35.5 & 111 \\
\hline 43.2 & 115 & 36.9 & 106 \\
\hline 46.4 & 116 & 38.5 & 113 \\
\hline 53.8 & 118 & 40.9 & 114 \\
\hline 63.1 & 300 & 41.3 & 008 \\
\hline \multirow[t]{5}{*}{64.0} & 302 & 43.9 & 115 \\
\hline & & 47.3 & 116 \\
\hline & & 55.3 & 118 \\
\hline & & 62.9 & 300 \\
\hline & & 64.2 & 216 \\
\hline
\end{tabular}

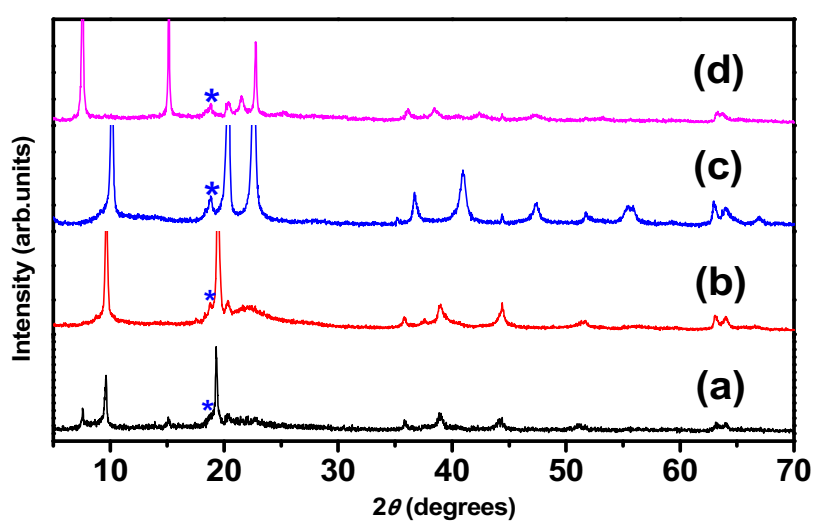

Figure 2. PXRD patterns of (a) b-[Li-Al-ClO 4$]-\mathrm{ASP}$, (b) b-[Li$\left.\mathrm{Al}-\mathrm{ClO}_{4}\right]-\mathrm{T} 50,(\mathbf{c})$ b-[Li-Al-ClO 4$]-\mathrm{T} 100$ and (d) b-[Li-Al-ClO 4$]-$ RH80 LDH phases. The reflection marked by asterisk in each trace corresponds to unreacted bayerite.

obtained (figure $2 b$ ) and all the reflections could be indexed to a one-layer cell of monoclinic symmetry (table 2 ) with a non-orthogonal stacking angle, $\beta=100.6^{\circ}$. Two features of the PXRD profile stand out: (i) the second basal reflection $\left(19.4^{\circ} 2 \theta\right)$ is followed by a broad hump, and (ii) the profile in the mid- $2 \theta$ region of the PXRD pattern is similar to that of the as-prepared precursor, suggesting that the phase obtained at $50^{\circ} \mathrm{C}$ is structurally similar to the precursor. Heating has merely eliminated the hydrated motifs. On further heating to $100^{\circ} \mathrm{C}$, a new phase (b- $\left.\left[\mathrm{Li}-\mathrm{Al}-\mathrm{ClO}_{4}\right]-\mathrm{T} 100\right)$ was obtained with basal spacings $8.71 \AA\left(10.2^{\circ} 2 \theta\right)$ and $4.36 \AA\left(20.4^{\circ} 2 \theta\right)$ (figure 2c), respectively. A strong reflection is observed at $22.6^{\circ} 2 \theta$ in the close vicinity of the second basal reflection. 
All the observed reflections were indexed to a one-layer hexagonal cell with orthogonal stacking (table 2). Together with this, the broad hump seen at $50^{\circ} \mathrm{C}$ is eliminated. These changes were reversed on cooling to $50^{\circ} \mathrm{C}$ showing that features in the PXRD profile of figure $2 \mathrm{~b}$ are structural in origin. Cooling and rehydration $(\mathrm{RH} \sim 80 \%)$ of the b-[Li-Al-ClO $\left.{ }_{4}\right]-$ $\mathrm{T} 100$ phase resulted in a $11.7 \AA$ phase (b- $\left[\mathrm{Li}-\mathrm{Al}-\mathrm{ClO}_{4}\right]-\mathrm{RH} 80$ ) (table 2, figure $2 \mathrm{~d}$ ) of hexagonal symmetry. The expansion in the basal spacing by $3 \AA$ is due to the massive ingress of water into the interlayer. This is accompanied by turbostratic disorder as shown by the weak, broad and ill-defined $h k l$ reflections.

\subsection{Polytype identification in $\mathrm{g}-\left[\mathrm{Li}-\mathrm{Al}-\mathrm{ClO}_{4}\right]$ and $b$ - $\left[\mathrm{Li}-\mathrm{Al}-\mathrm{ClO}_{4}\right] \mathrm{LDHs}$}

The [Li-Al] LDHs comprise covalently bonded metal hydroxide layers of the composition $\left[\mathrm{LiAl}_{2}(\mathrm{OH})_{6}\right]^{+}$(denoted by the symbol P), which are stacked one above another and bound by weak forces. The structure and symmetry of the metal hydroxide layers (layer group $p \overline{3} 12 / m ; a=b=5.12 \AA$ ) remain invariant in the cohort of compounds with different anions. The stacking sequence of the layers varies with the molecular symmetry, size, charge and orientation of the anions in the interlayer region giving rise to the phenomenon of polytypism. A series of DIFFaX [18,19] simulations of the PXRD patterns were carried out to identify the stacking sequences of the metal hydroxide layers in the various phases obtained by in situ humidity and temperature variations. The PXRD patterns of g-[ $\left.\mathrm{Li}-\mathrm{Al}-\mathrm{ClO}_{4}\right]-\mathrm{ASP}$ and g-[Li-Al-ClO 4 ]T140 LDHs matched with the PXRD patterns simulated with a $(0,0,1)$ stacking vector for a $\cdots P \bar{P} P \cdots$ stacking sequence $(\overline{\mathrm{P}}$ : mirror image of $\mathrm{P})$, compatible with a two-layer cell of hexagonal symmetry (polytype $2 \mathrm{H}$ ) (supplementary figure S1).

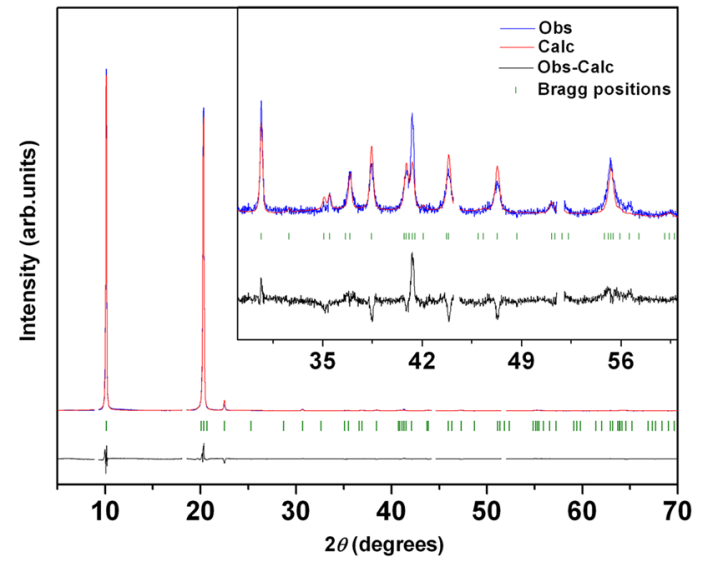

(a)

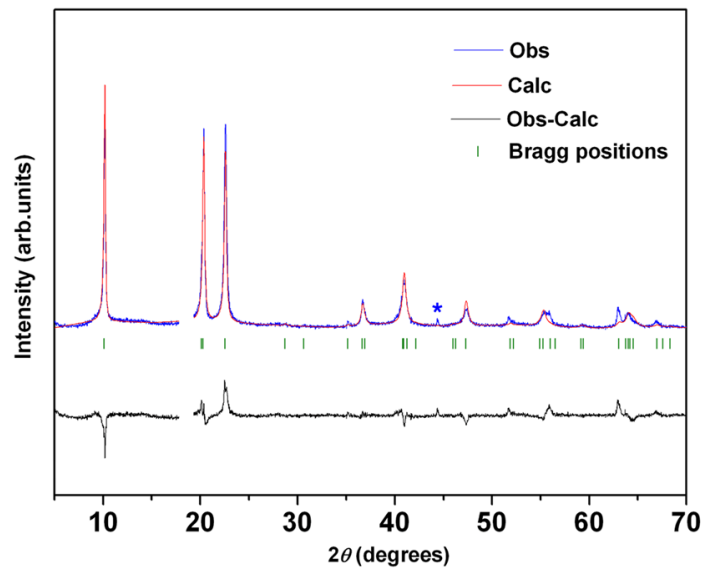

(b)

Figure 3. Full-profile fits of the PXRD patterns of (a) g-[Li-Al$\left.\mathrm{ClO}_{4}\right]-\mathrm{T} 140$ and (b) b-[Li-Al-ClO 4$]-\mathrm{T} 100$ obtained using code FOX. The asterisk in trace (b) corresponds to an unidentified impurity.

Table 2. Observed $2 \theta$ values and the corresponding indices of b- $\left[\mathrm{Li}-\mathrm{Al}-\mathrm{ClO}_{4}\right] \mathrm{LDH}$ obtained at different temperatures and humidity.

\begin{tabular}{|c|c|c|c|c|c|}
\hline \multicolumn{2}{|c|}{ b-[Li-Al-ClO 4$]-\mathrm{T} 50$} & \multicolumn{2}{|c|}{$\mathrm{b}-\left[\mathrm{Li}-\mathrm{Al}-\mathrm{ClO}_{4}\right]-\mathrm{T} 100$} & \multicolumn{2}{|c|}{ b-[Li-Al-ClO 4$]-\mathrm{RH} 80$} \\
\hline \multicolumn{2}{|c|}{$\begin{array}{l}a=5.0974 \AA, b=8.8258 \AA \\
c=9.2929 \AA, \beta=100.6^{\circ}, \\
\text { FM value }=7.4\end{array}$} & \multicolumn{2}{|c|}{$\begin{array}{c}a=b=5.11 \AA, \\
c=8.7041 \AA, \gamma=120^{\circ}, \\
\text { FM value }=12.9\end{array}$} & \multicolumn{2}{|c|}{$\begin{array}{c}a=b=5.0919 \AA, \\
c=11.6994 \AA, \gamma=120^{\circ}, \\
\text { FM value }=10.4\end{array}$} \\
\hline $2 \theta^{\circ}$ & $h k l$ & $2 \theta^{\circ}$ & $h k l$ & $2 \theta^{\circ}$ & $h k l$ \\
\hline 9.7 & 001 & 10.2 & 001 & 7.6 & 001 \\
\hline 19.4 & 002 & 20.4 & 002 & 15.1 & 002 \\
\hline 20.3 & -110 & 22.6 & 101 & 20.3 & 100 \\
\hline 35.8 & -131 & 36.7 & 111 & 21.6 & 101 \\
\hline 37.6 & -123 & 41.0 & 112 & 22.8 & 003 \\
\hline 39.0 & 201 & 47.4 & 113 & 36.1 & 111 \\
\hline 44.3 & 202 & 52.0 & 203 & 38.5 & 112 \\
\hline 51.3 & 203 & 55.5 & 114 & 42.4 & 113 \\
\hline 63.2 & -331 & 63.0 & 300 & 47.4 & 203 \\
\hline \multirow[t]{2}{*}{64.1} & -332 & 64.0 & 301 & 63.3 & 300 \\
\hline & & 66.9 & 302 & 63.8 & 301 \\
\hline
\end{tabular}




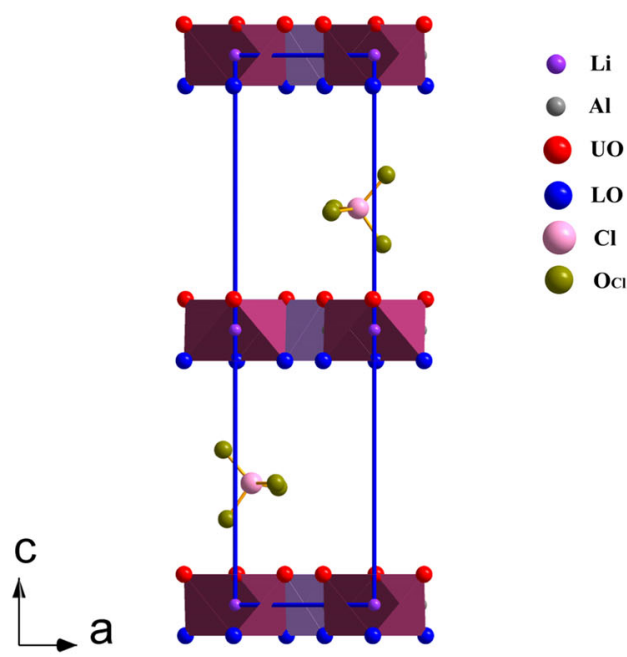

(a)

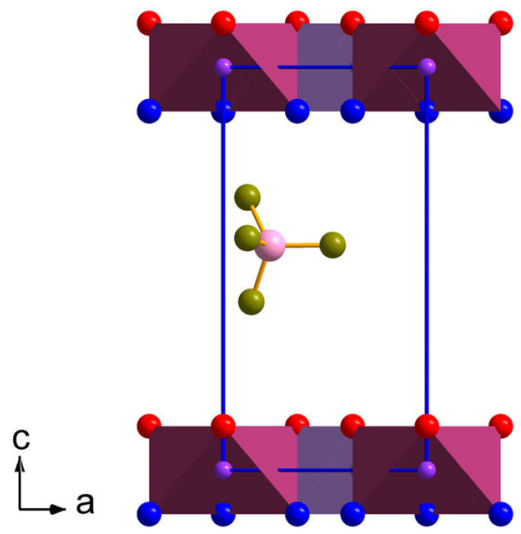

(b)

Figure 4. Structure models of (a) g-[Li-Al-ClO 4$]-\mathrm{T} 140$ and (b) b-[Li-Al-ClO 4$]-\mathrm{T} 100$.

Table 3. Results of structure refinement in direct space obtained from code FOX.

\begin{tabular}{lcc}
\hline & $\mathrm{g}-\left[\mathrm{Li}-\mathrm{Al}-\mathrm{ClO}_{4}\right]-\mathrm{T} 140$ & $\mathrm{~b}-\left[\mathrm{Li}-\mathrm{Al}-\mathrm{ClO}{ }_{4}\right]-\mathrm{T} 100$ \\
\hline Molecular formula & {$\left[\mathrm{Li}_{2} \mathrm{Al}_{4}(\mathrm{OH})_{12}\right]\left(\mathrm{ClO}_{4}\right)_{2}$} & {$\left[\mathrm{LiAl}_{2}(\mathrm{OH})_{6}\right]\left(\mathrm{ClO}_{4}\right)$} \\
Crystal symmetry & Hexagonal & Hexagonal \\
Space group & $P 6_{3} / m$ & $P \overline{3} 1 m$ \\
Cell parameters & & \\
$a(\AA)$ & 5.1122 & 5.1156 \\
$b(\AA)$ & 5.1122 & 5.1156 \\
$c(\AA)$ & 17.4820 & 8.7656 \\
$\beta(\mathrm{deg})$ & 90 & 90 \\
$R_{\mathrm{wp}}$ & 0.1465 & 0.1653 \\
$R_{\mathrm{p}}$ & 0.0460 & 0.1533 \\
$\mathrm{GoF}$ & 11.5029 & 3.7675 \\
\hline
\end{tabular}

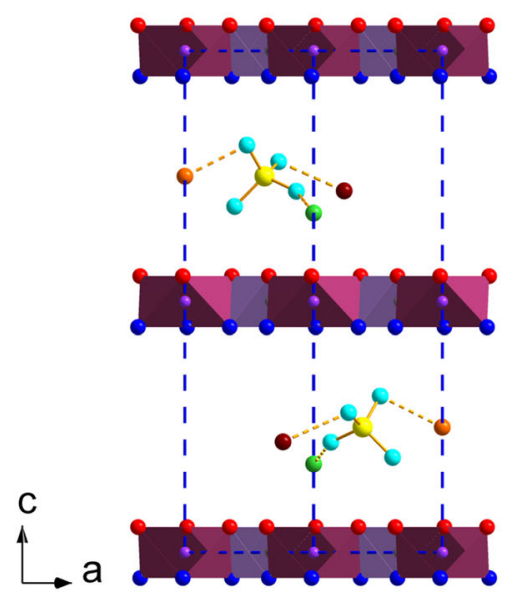

(a)
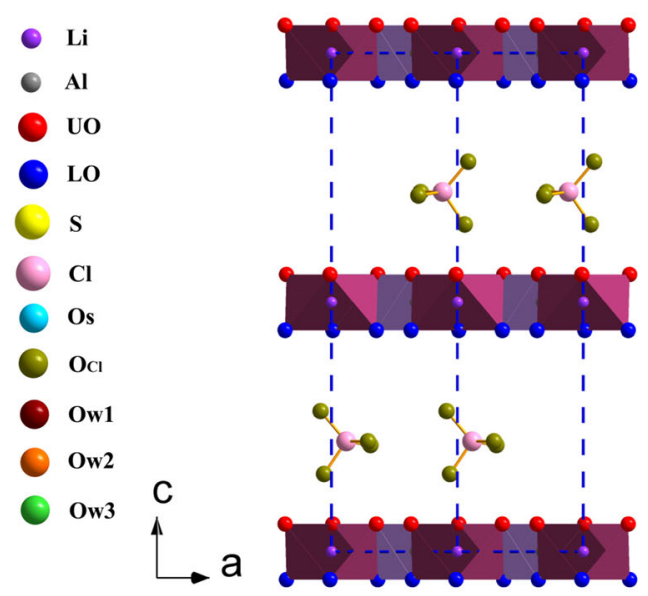

(b)

Figure 5. A schematic comparison of the packing of atoms in (a) g-[Li-Al-SO $\left.\mathrm{SO}_{4}\right] \mathrm{LDH}$ [13] with that in (b) g-[Li-Al-ClO 4 ] LDH. 


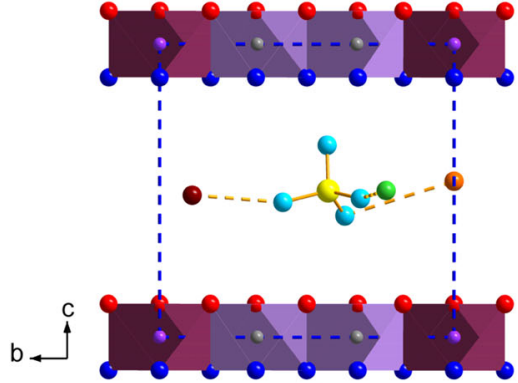

(a)

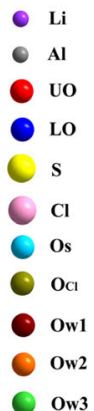

Ow3

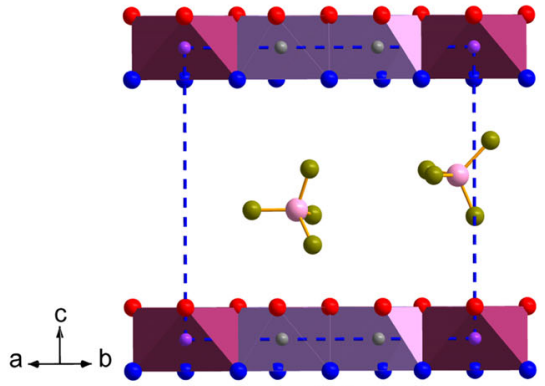

(b)

Figure 6. A schematic comparison of the packing of atoms in (a) b-[Li-Al-SO 4$]$ LDH [13] with that in (b) b- $\left[\mathrm{Li}-\mathrm{Al}-\mathrm{ClO}_{4}\right] \mathrm{LDH}$.

The PXRD patterns of all the $\mathrm{b}-\left[\mathrm{Li}-\mathrm{Al}-\mathrm{ClO}_{4}\right]$ phases were simulated with ... P P P ... stacking of the metal hydroxide layers. The $(2 / 3,0, \mathrm{z})$ stacking vector yielded the PXRD pattern of b-[Li-Al- $\left.\mathrm{ClO}_{4}\right]-\mathrm{T} 50$ (supplementary figure $\mathrm{S} 2$ ). The fractional relative translation of successive layers along the $a$ crystallographic axis yielded a stacking angle $100.5^{\circ}$, which matches the $\beta=100.6^{\circ}$ (table 2) of the monoclinic cell. The PXRD patterns of both b-[Li-Al-ClO 4$]-\mathrm{T} 100$ and RH80 phases (supplementary figure S2) could be simulated using a $(0,0,1)$ stacking vector. The orthogonal stacking generates a one-layer cell of hexagonal symmetry (polytype $1 \mathrm{H}$ ) for both b-[Li-Al-ClO $\left.{ }_{4}\right]-\mathrm{T} 100$ (table 2, $c=8.70 \AA$ ) and b-[Li$\left.\mathrm{Al}-\mathrm{ClO}_{4}\right]-\mathrm{RH} 80$ (table $2, c=11.70 \AA$ ) phases.

\subsection{Packing of $\mathrm{ClO}_{4}^{-}$ions in the interlayer of g-[ $\left.\mathrm{Li}-\mathrm{Al}_{-} \mathrm{ClO}_{4}\right]-\mathrm{Tl} 40$ and $\mathrm{b}$-[Li-Al-ClO$\left.{ }_{4}\right]-\mathrm{TlOO}$ phases}

Earlier work on the closely related sulphate-intercalated LDHs [13] and the reflection conditions in table 1 suggested the space group $P 6_{3} / \mathrm{m}$ for the two-layered g-[Li-Al-ClO 4 ]T140 and $P \overline{3} 1 \mathrm{~m}$ for the one-layered b-[Li-Al-ClO $\left.{ }_{4}\right]-\mathrm{T} 100$ phase, respectively. LeBail fits of the PXRD patterns of the two phases were found to be satisfactory. Partial structure models were extracted for the two phases from the refined structures of g-[Li-Al-Cl] [20] and b-[Li-Al-Br] [11], respectively, and were introduced into code $\mathrm{FOX}$ [21]. The $\mathrm{ClO}_{4}^{-}$ion was introduced as a molecule in the interlayer region. Code FOX refines the structure in the direct space. The $\mathrm{ClO}_{4}^{-}$ion was allowed to randomly translate and rotate within the interlayer space. The structure was optimized by a Monte Carlo approach using the $R$-values as cost functions to secure a good fit of the observed and calculated PXRD patterns (figure 3).

In the case of $\mathrm{g}-\left[\mathrm{Li}-\mathrm{Al}-\mathrm{ClO}_{4}\right]-\mathrm{T} 140$, the nominal molecular formula corresponds to $\left[\mathrm{Li}_{2} \mathrm{Al}_{4}(\mathrm{OH})_{12}\right]\left(\mathrm{ClO}_{4}\right)_{2}$. Of the two $\mathrm{ClO}_{4}^{-}$ions, one occupies the upper interlayer region and the other occupies the lower interlayer region in a two-layer unit cell (figure $4 \mathrm{a}$ ). The $\mathrm{Cl}$ atom of the $\mathrm{ClO}_{4}^{-}$ion occupies a general position of multiplicity $12 i$, which is in close proximity to the $\mathrm{Li}$ ions. The $C_{3}$ axis of the $\mathrm{ClO}_{4}^{-}$ion is observed to be tilted away from the stacking direction and the $C_{2}$ axis is parallel to the metal hydroxide layer. The $R$-values at this stage
$\left(R_{\mathrm{wp}}=14.9 \%, R_{\mathrm{p}}=4.7 \%\right)$ were found to be satisfactory (table 3). Structure refinement of g-[Li-Al-ClO 4$]-\mathrm{T} 140$ phase in the reciprocal lattice by the conventional Rietveld method was not attempted on account of the massive orientation of the crystallites. In the structure of b-[Li-Al- $\left.\mathrm{ClO}_{4}\right]-\mathrm{T} 100$ (nominal molecular formula $\left.\left[\mathrm{LiAl}_{2}(\mathrm{OH})_{6}\right] \mathrm{ClO}_{4}\right)$ predicted by code FOX, the $\mathrm{ClO}_{4}^{-}$ion adopts a position and orientation similar to that of the gibbsite-derived analogue (figure 4b). The $R$ values obtained from FOX at this stage are $R_{\mathrm{wp}}=16.5 \%$, $R_{\mathrm{p}}=15.3 \%$ (table 3$)$.

\section{Discussion}

The interlayer chemistry of the $\mathrm{ClO}_{4}^{-}$ions in LDHs is of special interest due to its chemical nature. Perchlorate is a monovalent polyatomic oxoanion with $\mathrm{Cl}$ in its highest oxidation state $(+7)$. Among the various oxoanions, free $\mathrm{ClO}_{4}^{-}$, like $\mathrm{SO}_{4}^{2-}$, is a spherical top molecule with $T_{d}$ molecular symmetry. Both anions have a similar ionic radius $(\sim 2.4 \AA)$ [22]. The $\mathrm{ClO}_{4}^{-}$ion has small charge to size ratio and a low hydration enthalpy $\left(-\Delta \mathrm{H}^{\circ}=229 \mathrm{~kJ} \mathrm{~mol}^{-1}\right)$ compared to that of the $\mathrm{SO}_{4}^{2-}$ ion $\left(-\Delta \mathrm{H}^{\circ}=1059 \mathrm{~kJ} \mathrm{~mol}^{-1}\right)$ [23]. The hydration of monoatomic anions is well studied due to the localization of the electron density. The non-uniform distribution of charge in polyatomic anions makes their hydration more complex, where the interaction with the surrounding water differs at different sites of the anions. Computations and experiments have shown that the hydration shell of both $\mathrm{SO}_{4}^{2-}$ and $\mathrm{ClO}_{4}^{-}$ ions has a spherical symmetry regardless of the orientation of the ions and the exchange dynamics. The primary difference between the two anions arises from the weaker hydrogen bonds formed by the $\mathrm{ClO}_{4}^{-}$ions with the water molecules, resulting in their higher mobility and greater exchange kinetics when compared to the $\mathrm{SO}_{4}^{2-}$ ions. In the case of the $\mathrm{SO}_{4}^{2-}$ ions, the water molecules in the first hydration shell are bonded strongly in comparison with the water molecules in the outer shells. As a result, the hydration shell and bulk water are clearly distinguished in $\mathrm{SO}_{4}^{2-}$ [24]. Given such similarities and differences in the hydration behaviour of the $\mathrm{ClO}_{4}^{-}$ 
anions with that of $\mathrm{SO}_{4}^{2-}$, the g-[Li-Al- $\left.-\mathrm{ClO}_{4}\right]-\mathrm{T} 140$ and b$\left[\mathrm{Li}-\mathrm{Al}-\mathrm{ClO}_{4}\right]-\mathrm{T} 100$ structure models were compared with the refined structures of the $\mathrm{g}$-[Li-Al-SO $\left.\mathrm{SO}_{4}\right]\left(T=100^{\circ} \mathrm{C}\right)[13]$ and b-[Li-Al-SO ${ }_{4}$ ] $\left(T=120^{\circ} \mathrm{C}\right)$ [13], respectively (figures 5 and 6). The comparison provides an insight into the packing of the $\mathrm{ClO}_{4}^{-}$ions in the interlayer region with a volume same as that in $\mathrm{SO}_{4}^{2-}$ intercalated LDHs.

The $\mathrm{g}$-[Li-Al-SO $\left.\mathrm{L}_{4}\right]\left(T=100^{\circ} \mathrm{C}\right) \mathrm{LDH}$ phase [13] has a molecular formula $\left[\mathrm{Li}_{2} \mathrm{Al}_{4}(\mathrm{OH})_{12}\right] \mathrm{SO}_{4} \cdot 3 \mathrm{H}_{2} \mathrm{O}$, and the $\mathrm{SO}_{4}^{2-}$ ion is not fully deprived of its hydration sphere. The three water molecules (Ow1, Ow2 and Ow3) together fill one interlayer site of the two-layer unit cell (figure 5a). The water molecules in the interlayer region form strong H-bonds with both the layer and $\mathrm{SO}_{4}^{2-}$ ions, thereby, stabilizing the $\mathrm{LDH}$ structure. The g-[Li-Al-ClO 4$]-\mathrm{T} 140$ phase, on the other hand, is completely dehydrated due to the low hydration enthalpy of the $\mathrm{ClO}_{4}^{-}$ions. The second perchlorate ion occupies the region of interlayer space occupied by the water molecules in the sulphate-LDH (figure 5b). When the sulphate LDH is completely dehydrated, the layered structure itself collapses. A similar phenomenon is observed in the interlayer of b-[Li-Al-SO $\left.\mathrm{S}_{4}\right]$ and b-[Li-Al-ClO $\left.{ }_{4}\right]-\mathrm{T} 100 \mathrm{LDHs}$ (figure 6).

\section{Conclusions}

Lithium perchlorate imbibition into both bayerite and gibbsite led to the formation of perchlorate-intercalated LDHs of $\mathrm{Li}$ and $\mathrm{Al}$. Both the LDHs reversibly take up water molecules from the ambient humidity and exhibit basal spacing dynamics. The gibbsite-derived LDH did not undergo any polytype changes during reversible hydration. The bayerite-derived $\mathrm{LDH}$ underwent a $1 \mathrm{M} \leftrightarrow 1 \mathrm{H}$ interpolytype transition during reversible hydration. In contrast with the sulphate-intercalated $\mathrm{LDH}$, the perchlorate-LDH dehydrates completely at $T>$ $100-140^{\circ} \mathrm{C}$ and the perchlorate ions occupy all the available interlayer sites.

\section{Acknowledgements}

We thank the Department of Science and Technology (DST), Government of India (GOI), for financial support. LP is a recipient of support under the Women Scientists (WOS-A) Scheme of the DST.

\section{References}

[1] Megaw H D 1934 Z. Kristallogr. 87185

[2] Rothbauer R, Zigan F and O’Daniel H 1967 Z. Kristallogr. 125 317

[3] Lipin V A 2001 Russ. J. Appl. Chem. 74184

[4] Clark G R, Rodgers K A and Henderson G S 1998 Z. Kristallogr. 21396

[5] Williams G R, Norquist A J and O'Hare D 2004 Chem. Mater. 16975

[6] Fogg A M and O'Hare D 1999 Chem. Mater. 111771

[7] Besserguenev A V, Fogg A M, Francis R J, Price S J, O'Hare D, Isupov V P et al 1997 Chem. Mater. 9241

[8] Serna C J, Rendon J L and Iglesias J E 1982 Clays Clay Miner. 30180

[9] Britto S and Kamath P V 2009 Inorg. Chem. 4811646

[10] Nagendran S, Periyasamy G and Kamath P V 2016 Dalton Trans. 4518324

[11] Nagendran S and Kamath P V 2017 Inorg. Chem. 565026

[12] Nagendran S, Periyasamy G and Kamath P V 2018 J. Solid State Chem. 266226

[13] Pachayappan L and Kamath P V 2019 Clays Clay Miner. 67 154

[14] Britto S and Kamath P V 2011 Inorg. Chem. 505619

[15] Hou X, Bish D L, Wang S L, Johnston C T and Kirkpatrick R J 2003 Am. Miner. 88167

[16] Poeppelmeier K R and Hwu S J 1987 Inorg. Chem. 263297

[17] Hou X and Kirkpatrick R J 2002 Chem. Mater. 14 1195

[18] Treacy M M J, Newsam J M and Deem M W 1991 Proc. Math. Phys. Eng. Sci. p 499

[19] Treacy M M J, Deem M W and Newsam J M 2005 DIFFaX version 1.812. http://www.public.asu.edu/ mtreacy/DIFFaX. html

[20] Nagendran S and Kamath P V 2013 Eur. J. Inorg. Chem. 2013 4686

[21] Favre-Nicolin V and Černý R 2002 J. Appl. Crystallogr. 35 734

[22] Marcus Y 1988 J. Solution Chem. 881475

[23] Smith D W 1977 J. Chem. Educ. 54540

[24] Eklund L 2014 Hydration of oxo anions. A combined computational and experimental structure and dynamics study in aqueous solutions, Swedish University of Agricultural Sciences: Uppsala 